\title{
Effect of dietary levels of hog plum (Spondias mombin) leaf meal on blood profile of
}

\section{Red Sokoto bucks}

${ }^{1}$ Bishir, B. B., ${ }^{2}$ Iyeghe-Erakpotobor, G. T., ${ }^{3}$ Zahraddeen, D. and ${ }^{1}$ Aliyu, A. M.

${ }^{\prime}$ National Agricultural Extension Research and Liaison Service, Ahmadu Bello University, Zaria

${ }^{2}$ National Animal Production Research Institute, Ahmadu Bello University Zaria

${ }^{3}$ Department of Animal Science, Ahmadu Bello University, Zaria

Corresponding author: bishirbellobakori@gmail.com;+2347069068696

\section{Abstract}

This research was carried out to update the baseline data on haematology and serum biochemical parameters of Red Sokoto bucks. The Bucks were allotted to five treatments having three replicates each in a completely randomized design. The hog plum leaf meal (HPLM) was fed at levels of 0, 10, 20, 30 and 40\% in treatment 1, 2, 3, 4 and 5 respectively. The experimental diets and clean drinking water were offered to the animals ad libitum. $2 \mathrm{~mL}$ of blood was taken for heamatological analysis and placed in a vacuum tube containing $10 \%$ ethylene diamine tetra acetic acid (EDTA). Measured parameters include packed cell volume $(P C V)$, haemoglobin concentration $(\mathrm{Hb})$, red blood cell $(\mathrm{RBC})$, white blood cells $(W B C)$, Neutrophils, Basophils, Eosinophils, Monocytes and Lymphocytes and another $2 \mathrm{~mL}$ of blood sample was also taken for serum biochemistry analysis and was also placed in a separate vaccum tube without anti-clotting agent. Measured parameters for serum biochemistry include glucose, total protein, albumin, globulin, urea, creatinine, sodium, potassium and chlorine. Packed cell volume (PCV), red blood cells (RBC), white blood cells (WBC), haemoglobin $(\mathrm{Hb})$, neutrophils, eosinophils and lymphocytes differed $(P<0.05, P<0.01)$ among treatments. However, basophils and monocytes were not significantly $(P>0.05)$ affected. The white blood cells differentials were slightly different between treatment groups but were within the reference range. The relative Lymphocytes counts was higher $(P<0.05)$ in $30 \%$ and $40 \%$ HPLM T5 $(72.42 \%, 73.57 \%)$ than other treatments groups which were $70.23 \%, 65.17 \%$ and $70.31 \%$ for 0,10 and 20\% HPLM, respectively. The serum glucose values obtained in this study The values obtained for total protein, globulin and potassium were not significantly different $(P<0.05)$. The albumin and urea values obtained have the lowest value at $3.82 \mathrm{~g} / \mathrm{l}$ (control) and $30 \%$ HPLM (4.46mmol/l) respectively. Creatinine and sodium were significantly higher in 40\% (147.00mmol/l) and 20\% HPLM (169.33mmol/l) respectively and Values for chlorine was observed to be similar $(P<0.0 .05)$ having the lowest value at $10 \%$ HPLM $(84.23 \mathrm{mmol} / \mathrm{l})$. were significantly higher $(P<0.05)$ on $10 \%(8.00$ $\mathrm{mmol} / \mathrm{l})$ and $20 \% \mathrm{HPLM}(8.36 \mathrm{mmol} / \mathrm{l})$ respectively. The study indicated that hog plum leaf meal could be used as feed resources to raise goats.

Keywords: Hog plum, haematology, Red Sokoto

\section{Un Effet des niveaux diététiques de la farine de feuille de prune de porc (Mombin de Spondias) sur le profil sanguin des mâles rouges de Sokoto}

\section{Résumé}

Cette recherche a été effectuée pour mettre à jour les données de base sur l'hématologie et les paramètres biochimiques sériques des mâles Sokoto rouges. Les Bucks ont été attribués à 


\section{Effect of dietary levels of hog plum (Spondias mombin) leaf meal on blood profile}

cinq traitements ayant trois répliques chacun dans une conception complètement randomisée. La farine de feuilles de prunier (HPLM) a été nourrie à des niveaux de 0, 10, 20, 30 et $40 \%$ dans le traitement 1, 2, 3, 4 et 5 respectivement. Les régimes expérimentaux et l'eau potable propre ont été offerts aux animaux ad libitum. $2 \mathrm{~mL}$ de sang a été pris pour l'analyse hématologique et placé dans un tube à vide contenant 10\% d'acide tétra acetic d'éthylène diamine (EDTA). Les paramètres mesurés comprennent le volume cellulaire emballé (PCV), la concentration d'hémoglobine (Hb), les globules rouges (RBC), les globules blancs (WBC), les neutrophiles, les basophiles, les éosinophiles, les monocytes et les lymphocytes et un autre échantillon de sang de $2 \mathrm{~mL}$ a également été prélevé pour l'analyse de biochimie sérique et a également été placé dans un tube d'évacuation séparé sans agent anticoagulation. Les paramètres mesurés pour la biochimie sérique comprennent le glucose, la protéine totale, l'albumine, la globuline, l'urée, la créatinine, le sodium, le potassium et le chlore. Le volume de cellules emballées (PCV), les globules rouges (RBC), les globules blancs $(W B C)$, l'hémoglobine (Hb), les neutrophiles, les éosinophiles et les lymphocytes différaient $(P<0,05$, $P<0,01)$ parmi les traitements. Cependant, les basophiles et les monocytes n'ont pas été affectés de manière significative $(P>0,05)$. Les différentiels des globules blancs étaient légèrement différents entre les groupes de traitement, mais se trouvaient dans la fourchette de référence. Les comptes relatifs de lymphocytes étaient plus élevés $(P<0.05)$ dans $30 \%$ et $40 \%$ HPLM T5 (72.42\%, 73.57\%) que les autres groupes de traitements qui étaient 70,23\%, $65,17 \%$ et $70,31 \%$ pour 0,10 et 20\% HPLM, respectivement. Les valeurs de glucose sérique obtenues dans cette étude Les valeurs obtenues pour la protéine totale, la globuline et le potassium n'étaient pas significativement différentes $(P<0,05)$. Les valeurs d'albumine et d'urée obtenues ont la valeur la plus basse à 3,82 $\mathrm{g} / \mathrm{l}$ (contrôle) et $30 \% \mathrm{hplm}(4,46 \mathrm{mmol} / \mathrm{l})$ respectivement. La créatinine et le sodium étaient significativement plus élevés dans $40 \%$ (147.00mmol/l) et 20\% HPLM (169.33mmol/l) respectivement et les valeurs pour le chlore ont été observées pour être semblables $(P<0.0 .05)$ ayant la valeur la plus basse à $10 \%$ HPLM $(84.23 \mathrm{mmol} / \mathrm{l})$. étaient significativement plus élevés $(P<0,05)$ sur $10 \%(8,00 \mathrm{mmol} / \mathrm{l})$ et $20 \%$ HPLM (8,36 mmol/l) respectivement. L'étude a indiqué que la farine de feuilles de prunier pourrait être utilisée comme ressources d'alimentation pour élever des chèvres.

Mots-clés: de prune de porc, hématologique, des mâles Sokoto rouges

\section{Introduction}

Increasing productivity is one of the primary goals in goat production. The level of production achieved in any particular livestock farm is a function of the unique combination of the animals, feeding management, environment and health care factors (Thornton, 2010). Nutrition is the single most important factor militating against livestock production in Nigeria. Malnutrition especially in the dry season when herbage quality is low is a problem. Lack of improvement in crop yields and competition between humans and animals for available grains makes nutritional requirement at reasonable cost more difficult to achieve (Tilman et al., 2002). Hog plum (Spondias mombin) is a small deciduous tree plant of up to $20 \mathrm{~m}$ height and occurs in a great variety of humid tropical climates. Its fruits, bark, leaves and roots are of great importance agriculturally and otherwise. Its leaves make excellent fodder for livestock. The fruits are also of great nutritional value (Oladele, 2008). The leaves are more readily available and cheap especially during the dry seasons when most other forages are in short supply. Well dried leaves can be stored for long periods of time (Aregheore et al., 2003). 
Conventional basal energy feeds are scarce and becoming increasingly expensive in Nigeria. The inclusion of alternative feeding stuffs in animal diet might be interesting in some circumstances (relative price, feed quality) which is limited because of lack of information in their value (Famino et al., 2003). The assessment of the nutritional and health status of animals can effectively be determined by using certain blood metabolite concentrations such as non-essential fatty acids (NEFA), $\beta$ hydroxybutyrate (BHA), glucose and cholesterol (Ndlovu et al., 2007). These metabolite concentrations indicate the extent of the metabolism of energy, proteins and other nutrients in animals (PambuGollah et al., 2000; Agenas et al., 2006). The changes in the circulating nutrientssensitive metabolite concentrations are important signals of the metabolic status of the animal and organs function (Lindsay et al., 1993, Wettemann et al., 2003). Other blood metabolites, such as total protein, albumin, globulin, creatinine, and urea, serve as indicators of the protein status of the animal. Factors indicating the physiological status of an animal, health status of an animal, breed, nutrition, season and age may affect the concentration of these metabolites in the blood (Ndlovu et al., 2007). Haematological examination has been performed for a variety of reasons: as a screening procedure to examine general health of the animal, for assessing the nutritional status of the animal, as an adjunct to infection and to evaluate the progress of certain disease conditions (Friday et al., 2014) and to distinguish between normal and stress conditions of the animal (Olabanji et al., 2007). Haematological values provide baseline information for comparison in conditions of nutrients deficiency, physiology and health status of farm animals (NseAbasi et al., 2014) and help in providing information on the relationship between blood characteristics and environment (Ovuru and Ekweozor, 2004, Isaac et al., 2013).

\section{Materials and methods Experimental site}

The study was conducted at the Teaching and Research Farm of the Department of Animal Science, Faculty of Agriculture, Ahmadu Bello University, Zaria. Zaria is within Northern Guinea Savannah Zone of Nigeria, located on latitude $11^{\prime} 12^{\circ} \mathrm{N}$ and longitude $7133^{\circ} \mathrm{E}$ at an altitude of $610 \mathrm{~m}$ above the sea level (Ovimaps, 2015).

\section{Sources of feed ingredients}

Maize cobs were obtained from Bakori Local Government Area of Katsina State. The maize cobs were packed, processed and stored prior to feeding. Other feed ingredients which include cotton seed cake, wheat offal, bone meal and salt were purchased from the market.

\section{Anti-nutritional factor of hog plum leaves extract}

Prior to quantitative phytochemical analysis, phytochemical screening was carried out on the plant's leaf extract using standard methods as described by Sofowora (1982) and A.O.A.C. (2005). The percentage compositions of saponins, tannins and phytate were determined accordingly to the methods of Harborne (1973) and Treas and Evans (1989). Oxalate content was determined by spectrophotometric methods of Hang and Lantzsch (1983).

\section{Experimental animals and management}

Prior to the arrival of animals, the pens were cleaned and disinfected. Fifteen red Sokoto bucks of average weight range of $10-11 \mathrm{~kg}$ were used. On arrival, the animals were quarantined for three weeks; and administered ivomectin (Ivomec $($ ) $1 \%$ at a rate of $0.2 \mathrm{mg} / \mathrm{kg}$ body weight $(0.2 \mathrm{mg} / \mathrm{kg})$ and antibiotic Tetracycline LA $200 \mathrm{mg} / \mathrm{ml}$ against internal and external parasites and bacterial infection and were vaccinated against Peste des peptits ruminants (PPR) 
with Tacrive virus disease vaccine (TCRV) (William, 1997). They were allowed 14 days to adjust to feed and confinement before the actual start of the experiment. The animals were de-wormed with Albendazol $(10 \mathrm{mg} / \mathrm{kg})$ against internal parasites during confinement period (William, 1997).

\section{Experimental diets}

Five dietary treatments containing graded levels of hog plum dry leaves meal at 0,10 , 20,30 , and $40 \%$ inclusion rates were formulated and designated as T1, T2, T3, T4, and T5. T1 serve as the control which had no hog plum dry leaves (Table 3.1 and 3.2)

\section{Experimental design}

The Red Sokoto bucks were randomly allocated to five dietary treatment diets with three bucks per treatment in a completely randomized design. The feeding trials lasted for three months. The bucks were fed at $3 \%$ body weight. Groundnut haulms were also offered daily while water was provided ad libitum. Each buck was offered the treatment diet in 2 allocations daily, at 8:00 a.m and 4:00 p.m respectively. The left-over was collected the following morning and weighed before fresh feed was offered to determine the feed intake. All bucks were weighed at the beginning of the experiment and fortnightly thereafter to adjust the amount of feed given in order to maintain the pre-determined level of 3\% feeding of the animal's body weight for the period of the study.

\section{Haematological and serological} characteristics

About $4 \mathrm{~mL}$ of blood (2mls each for heamatology and serum analysis) was taken from the jugular vein of the bucks at the age of seven to eight month, using needle and hyperdemic syringes $(5 \mathrm{~mL})$, at two week intervals, at the onset, middle and end of the trial between 7:30 a.m to 8:30 a.m before feeding the animals. The blood samples were placed in vacuum tubes for hematological and serum biochemical analysis. $2 \mathrm{~mL}$ each of the blood sample for haematology and serum biochemical was placed in two separate vacuum tubes, one without anti-clotting agent for serum biochemistry analysis and the other with ethylene diamine tetra acetic acid (EDTA) for haematological analysis. Immediately after collection, the capped tubes containing the anti-coagulant and blood sample was innervated gently about 10 times. Samples of blood was transported using ice box with ice park to the Haematology Unit of the Department of Pathology, Faculty of Veterinary Medicine, Ahmadu Bello University, Zaria, for determination of haematological and serum biochemical parameters. In the laboratory, the haematological analysis was performed using a semi-automatic cell counter (Sysmex-F 820). Measured parameters include packed cell volume (PCV), haemoglobin concentration $(\mathrm{Hb})$, red blood cell (RBC), white blood cells (WBC) and total protein (Tp). Blood smears was separated as ethanol-fixed and stained according to the May-Grunwald-Giemsa technique, (2015). The blood smears were used to determine neutrophils (NL), eosinophils (EOS), basophils (BAS), and the differential WBC count were quantified by immersion refractometry. Blood plasma was separated by centrifugation at $1800 \mathrm{x} g$ for 15 minutes at $4^{\circ} \mathrm{C}$. The plasmas were stored at $-20^{\circ} \mathrm{C}$. Blood glucose was measured using glucose oxidase with an alternative oxygen acceptor based on the method of Trinder et al. (1969). The total blood protein concentration was determined based on the burette reaction (Doumas et al., 1981) and albumin determination as described by Doumas and Biggs (1972). Globulin concentration in plasma was computed as the difference between the total protein and albumin concentration (Mapekula et al., 2011). Urea determination was based on the 
method of Sampson et al. (1983), while creatinine determination was done according to the method of Ambros et al. (1983). Serum electrolytes: sodium, potassium, calcium and chlorine were analyzed using Roche AVL 9180 snap pack Electrolyte analyzer. The accuracy and reliability of the procedures, instruments and the reagents were ensured through quality control and careful handling of the samples.

\section{Chemical analysis}

The proximate composition of the hog plum leaf meal was determined as described by AOAC (2005). Nitrogen Free Extract (NFE) was determined by difference and Metabolizable Energy (ME) calculated according to the procedure of Pauzenga (1985) as: $\mathrm{ME}(\mathrm{kcal} / \mathrm{kg})=37 \mathrm{x} \%$ protein $+81.8 \mathrm{x} \%$ fat $+35.5 \mathrm{x}$ NFE.

\section{Statistical analysis}

Data obtained were subjected to analysis of variance (ANOVA) using SAS Statistical System (SAS, 2002). The means were separated using Dunnet test (Dunnet, 1955).

Table 1: Composition of experiment diet

Percentage inclusion levels of Spondias mombin dry leaves (\%)

\begin{tabular}{llllll}
\hline Feed composition $(\mathrm{kg})$ & 0 & 10 & 20 & 30 & 40 \\
\hline Spondias mombin & 0.00 & 10.00 & 20.00 & 30.00 & 40.00 \\
Cotton seed cake & 7.03 & 6.00 & 4.97 & 3.93 & 2.90 \\
Maize offal & 60.97 & 52.00 & 43.03 & 34.07 & 25.01 \\
Maize cob & 30.00 & 30.00 & 30.00 & 30.00 & 30.00 \\
Bone meal & 1.50 & 1.50 & 1.50 & 1.50 & 1.50 \\
Common salt & 0.50 & 0.50 & 0.50 & 0.50 & 0.50 \\
Total & 100.00 & 100.00 & 100.00 & 100.00 & 100.00 \\
Calculated analysis & & & & & \\
ME(kcal/kg) & 2285.324 & 2506.236 & 2628.374 & 2702.490 & 2813.576 \\
Crude protein \% & 11.45 & 11.26 & 12.34 & 12.53 & 12.62 \\
Crude fibre \% & 19.83 & 18.04 & 15.22 & 13.33 & 11.03 \\
Ether extract \% & 2.68 & 2.62 & 2.60 & 2.58 & 2.54 \\
\hline
\end{tabular}

$\mathrm{ME}=$ Metabolisable Energy in $\mathrm{Kcal} / \mathrm{kg}=(\% \mathrm{CPx} 37)+(\% \mathrm{EEx} 8.18)+(\% \mathrm{NFEx} 35) \ldots .($ Pauzenga, 1985$)$

\section{Results}

The result of the proximate compositions of the hog plum leaf meal diet used in this study (Table 2) showed that the dry matter, crude protein, crude fibre, ether extracts, ash, nitrogen free extract and metabolizable energy were $94.57 \%, 13.36 \%, 10.34 \%$, $2.95 \%, 9.86 \%, 67.87 \%$ and $2758.29 \mathrm{kcal} / \mathrm{kg}$ DM respectively.

The haematological components of Red Sokoto growing bucks (goats) fed hog plum (Spondias mombin) leaf meal are presented in Table 4. Significant differences were found between the treatment for PCV, RBC and WBC $(\mathrm{P}>0.05)$, There were no significant differences $(\mathrm{P}>0.05)$ in monocytes, and basophils among the experimental treatments. The relative neutrophil count was higher $(\mathrm{P}<0.05)$ on 30 and $40 \%$ HPLM $(32.86 \%, 33.73 \%)$ than in other treatment diets which were $30.33 \%$, $30.29 \%$ and $31.33 \%$ for 0,10 and $20 \%$ HPLM respectively, but all are within the reference range. Differential eosinophil counts were lowest $(\mathrm{P}<0.05)$ in $0 \%$ HPLM $(0.69 \%)$ and highest in $40 \%$ HPLM (2.03\%). The relative Lymphocytes counts was higher $(\mathrm{P}<0.05)$ in $30 \%$ and $40 \%$ HPLM T5 $(72.42 \%, 73.57 \%)$ than other treatments groups which were $70.23 \%$, $65.17 \%$ and $70.31 \%$ for 0,10 and $20 \%$ HPLM respectively. 


\section{Effect of dietary levels of hog plum (Spondias mombin) leaf meal on blood profile}

The result of serum biochemical indices of Red Sokoto bucks fed HPLM is shown in Table 5. The serum glucose values obtained were significantly higher $(\mathrm{P}<0.05)$ at $10 \%$ $(8.00 \mathrm{mmol} / \mathrm{l})$ and 20\% HPLM (8.36 $\mathrm{mmol} / \mathrm{l})$ respectively. The values obtained for total protein, globulin and potassium were not significantly different $(\mathrm{P}<0.05)$.
The albumin and urea values obtained had the lowest value at $0 \%(3.82 \mathrm{~g} / 1)$ and $30 \%$ HPLM (4.46 $\mathrm{mmol} / 1)$ respectively. Creatinine and sodium were significantly higher in $40 \%(147.00 \mathrm{mmol} / \mathrm{l})$ and $20 \%$ HPLM (169.33mmol/1) respectively and values for chlorine was observed to be similar $(\mathrm{P}<0.0 .05)$ having the lowest value at $10 \% \operatorname{HPLM}(84.23 \mathrm{mmol} / \mathrm{l})$.

Table 2: Chemical composition of hog plum leaf meal

\begin{tabular}{ll}
\hline Parameter $(\%)$ & Values \\
\hline Dry matter & 94.57 \\
Crude protein & 13.36 \\
Crude fibre & 10.34 \\
Ether extracts & 2.95 \\
Ash & 9.86 \\
Nitrogen free extract & 67.87 \\
ME (Kcal/kg) & 2758.29 \\
\hline
\end{tabular}

$\mathrm{ME}=$ Metabolisable Energy in $\mathrm{Kcal} / \mathrm{kg}=(\% \mathrm{CPx} 37)+(\% \mathrm{EEx} 8.18)+(\% \mathrm{NFEx} 35$. (Pauzenga, 1985)

Table 3 shows the results of anti-nutritional factors of hog plum leaf meal. Hog plum leaf meal contains $1.01 \mathrm{mg}$ phytate, $0.47 \mathrm{mg}$ oxalate, $0.38 \mathrm{mg}$ tannin and $2.70 \mathrm{mg}$ Saponin in every $100 \mathrm{~g}$ of Spondias mombin dry leaves.

Table 3: Anti-nutritional factor of hog plum leaf meal

\begin{tabular}{lc}
\hline Composition & $\mathrm{mg} / 100 \mathrm{~g}$ \\
\hline Phytate & 1.01 \\
Oxalate & 0.47 \\
Tannins & 0.38 \\
Saponin & 2.70 \\
\hline
\end{tabular}

Table 4: Effect of varying inclusion levels of hog plum leaf meal on haematological indices of Red Sokoto bucks

\begin{tabular}{|c|c|c|c|c|c|c|c|}
\hline \multirow{2}{*}{ Parameter } & \multicolumn{5}{|c|}{ Level of hog plum leaf meal (\%) } & \multirow[b]{2}{*}{ SEM } & \multirow[b]{2}{*}{ LOS } \\
\hline & 0 & 10 & 20 & 30 & 40 & & \\
\hline Pack cell volume $(\%)$ & $28.92^{\mathrm{d}}$ & $23.59^{\mathrm{e}}$ & $30.70^{\mathrm{c}}$ & $32.08^{\mathrm{b}}$ & $33.75^{\mathrm{a}}$ & 0.45 & $*$ \\
\hline Haemoglobin $(\mathrm{g} / \mathrm{dl})$ & $9.97^{\mathrm{d}}$ & $9.13^{\mathrm{e}}$ & $10.67^{\mathrm{c}}$ & $11.01^{\mathrm{b}}$ & $11.49^{\mathrm{a}}$ & 0.11 & * \\
\hline Red blood cell (x10 $/ 1)$ & $4.75^{\mathrm{cd}}$ & $3.68^{d}$ & $5.13^{\mathrm{c}}$ & $5.67^{\mathrm{b}}$ & $5.96^{\mathrm{a}}$ & 0.11 & $*$ \\
\hline White blood cell $\left(\mathrm{x} 10^{9} / 1\right)$ & $6.20^{\mathrm{a}}$ & $5.26^{\mathrm{b}}$ & $6.67^{\mathrm{a}}$ & $6.47^{\mathrm{a}}$ & $6.57^{\mathrm{a}}$ & 0.44 & * \\
\hline Neutrophils (\%) & $30.33^{\mathrm{c}}$ & $30.29^{c}$ & $31.33^{\mathrm{b}}$ & $32.86^{\mathrm{a}}$ & $33.73^{\mathrm{a}}$ & 0.49 & \\
\hline Basophils (\%) & 1.49 & 1.06 & 1.57 & 1.70 & 1.90 & 0.59 & NS \\
\hline Eosinophils (\%) & $0.69^{b}$ & $1.49^{\mathrm{a}}$ & $1.21^{\mathrm{a}}$ & $1.88^{\mathrm{a}}$ & $2.03^{\mathrm{a}}$ & 0.24 & $*$ \\
\hline Monocytes (\%) & 0.42 & 0.36 & 1.86 & 0.49 & 0.69 & 0.63 & NS \\
\hline Lymphocytes (\%) & $70.23^{b}$ & $65.17^{\mathrm{c}}$ & $70.31^{\mathrm{b}}$ & $72.42^{\mathrm{a}}$ & $73.57^{\mathrm{a}}$ & 0.93 & $*$ \\
\hline
\end{tabular}




\section{Bishir, Iyeghe-Erakpotobor, Zahraddeen and Aliyu}

Table 5 : Effect of varying inclusion I evels of hog plum leaf meal on serum b iochemical profile of Red Sokoto bucks

\begin{tabular}{lccccccc}
\hline & \multicolumn{9}{c}{ Level of hog plum leaf meal (\%) } & & & \\
\hline Parameters & 0 & 10 & 20 & 30 & 40 & SEM & LOS \\
\hline Glucose $(\mathrm{mmol} / \mathrm{L})$ & $7.15^{\mathrm{b}}$ & $8.00^{\mathrm{a}}$ & $8.36^{\mathrm{a}}$ & $7.62^{\mathrm{ab}}$ & $7.13^{\mathrm{b}}$ & 0.38 & $*$ \\
Total protein $(\mathrm{g} / \mathrm{dL})$ & 5.40 & 5.74 & 5.71 & 5.69 & 5.69 & 0.47 & $\mathrm{NS}$ \\
Albumin $(\mathrm{g} / \mathrm{L})$ & $3.82^{\mathrm{b}}$ & $4.18^{\mathrm{a}}$ & $4.04^{\mathrm{ab}}$ & $4.51^{\mathrm{a}}$ & $4.43^{\mathrm{a}}$ & 0.18 & $*$ \\
Globulin $(\mathrm{g} / \mathrm{l})$ & 1.58 & 1.56 & 1.66 & 1.18 & 1.26 & 0.46 & $\mathrm{NS}$ \\
Urea $(\mathrm{mmol} / \mathrm{L})$ & $4.55^{\mathrm{a}}$ & $4.68^{\mathrm{a}}$ & $4.70^{\mathrm{a}}$ & $4.46^{\mathrm{b}}$ & $4.89^{\mathrm{a}}$ & 0.19 & $*$ \\
Creatinine(mmol/L) & $121.67^{\mathrm{c}}$ & $125.00^{\mathrm{c}}$ & $127.67^{\mathrm{c}}$ & $136.67^{\mathrm{b}}$ & $147.00^{\mathrm{a}}$ & 3.29 & $*$ \\
Sodium $(\mathrm{mmol} / \mathrm{L})$ & $161.00^{\mathrm{b}}$ & $162.33^{\mathrm{b}}$ & $169.33^{\mathrm{a}}$ & $161.67^{\mathrm{b}}$ & $154.33^{\mathrm{c}}$ & 3.19 & $*$ \\
Potassium $(\mathrm{mmol} / \mathrm{L})$ & 4.83 & 5.11 & 4.86 & 4.81 & $? ?$ & 0.23 & NS \\
Chlorine $(\mathrm{mmol} / \mathrm{L})$ & $98.67^{\mathrm{a}}$ & $84.23^{\mathrm{c}}$ & $98.51^{\mathrm{a}}$ & $90.67^{\mathrm{b}}$ & $94.78^{\mathrm{a}}$ & 2.72 & $*$ \\
\hline
\end{tabular}

${ }^{\mathrm{abc}}$ means with different superscripts within the same row differed significantly $(\mathrm{P}<0.05), \mathrm{SEM}=\mathrm{Standard}$ Error of Mean, LOS= Level of Significance, NS=Not significant $\mathrm{P}$ value $(\mathrm{P}>0.05)$.

\section{Discussion}

Proximate crude protein content of Hog plum leaf meal in this present study $(13.36 \%)$ was slightly higher compared to the treatment diets which are approximately $12 \%$. The dry matter contents $94.57 \%$ were quite high. The crude fibre level was recorded as $10.34 \%$. The levels of ash, nitrogen free extract was $9.86 \%$ and $67.87 \%$, respectively. The result of antinutritional factors in hog plum leaf meal shows that there was phytate $1.01 \mathrm{mg}$, oxalate $0.47 \mathrm{mg}$, tannin $0.38 \mathrm{mg}$ and saponin $2.70 \mathrm{mg}$ in every $100 \mathrm{~g}$ of Spondias mombin dry leaves, which is highly tolerable by ruminants (Kumar 1991). The author observed that sheep ingesting up to $0.9 \mathrm{mg}$ hydrolysable tannins per kilogram body weight showed no toxicity. These phytochemicals exhibit various pharmacological and biochemical actions when ingested by animals. Saponin is a known anti-nutritional factor that can reduce the uptake of certain nutrients including cholesterol and glucose at the gut through intra-lumenal physicochemical interaction or other yet unidentified activity (Price et al., 1987). Furthermore, oxalate and saponin observed in the plant had lower concentrations and have been associated with the observed antimicrobial effects in various studies involving plant extracts. Significant differences were observed between the treatments for packed cell volume, red blood cell and white blood cell $(\mathrm{P}<0.05)$ while there were no differences $(\mathrm{P}>0.05)$ in monocytes, and basophils between the experimental treatments. The relative neutrophils counts were higher $(\mathrm{P}<0.05)$ on $30 \% \quad(32.86 \%)$ and $40 \%$ $(33.73 \%)$ HPLM than in other treatment diets, but all are within the reference range. Differential eosinophil counts were lower $(\mathrm{P}<0.05)$ in treatment $1(0.69 \%)$ and was higher in treatment $5(2.03 \%)$. The relative Lymphocytes counts was higher $(\mathrm{P}<0.05)$ in treatment $4(72.42 \%)$ and treatment 5 $(73.57 \%)$ than other treatments. The result obtained for packed cell volume (PCV) for Red Sokoto is not in agreement with the results obtained for Red Sokoto goats by Tambual et al. (2002). The findings of this study support that PCV varies among treatments. High PCV values indicate either an increase in the number of circulating $\mathrm{RBC}$ or reduction in circulating plasma volume (Kopp and Hetesa, 2000). Haematological traits especially PCV and $\mathrm{Hb}$ were correlated with nutritional status of the animal (Adejumo, 2004). Diets have been established to have measurable effects on blood components and are widely used in nutritional evaluation and survey of animals. The packed cell volume, red blood cell and hemoglobin values help to determine and classify anaemia (Jain, 


\section{Effect of dietary levels of hog plum (Spondias mombin) leaf meal on blood profile}

1986). The higher packed cell volume values observed in this study might likely be a sign of healthier goats (bucks). The results of the red blood cell showed that $40 \%$ HPLM had higher red blood cell values of $5.96 \times 10^{6} / \mathrm{L}$ than other treatments. This is a signal of the health status of Red Sokoto goats (bucks), which is in agreement with the findings of Schalm et al. (1975) and Addass et al. (2010) who reported that blood values of animals might be influenced by certain factors such as nutrition among others. The total white blood cell (WBC) count was higher in this study and is in agreement with result obtained for Red Sokoto goats by Tambual et al. (2002). The higher values of the white blood cell observed in this study may also be attributed to the management system (intensive) which makes them face challenges from microbes compared with free range. The neutrophils value obtained for Red Sokoto is in agreement with result obtained for Red Sokoto goat as reported by Tambual et al. (2002). Neutrophils were observed to be a very effective killing machine (Ganong, 2005). Monocytes and Basophils value obtained for Red Sokoto goats (bucks) were not significantly different and this is contrary to the result for Red Sokoto goats as reported by Tambual et al. (2002). The lymphocytes values obtained in this study were higher than the values (64.8 to $70 \%$ ) for a Red Sokoto goat by Opara et al. (2010) for Red Sokoto goat. The result shows that serum glucose, albumin, urea, creatinine, sodium and chlorine were significantly $(\mathrm{P}<0.05)$ affected by level of hog plum leaf meal, while total protein, globulin and potassium were not significantly $(\mathrm{P}>0.05)$ affected by the level of supplementation. The values obtained for blood glucose level varied $(\mathrm{P}<0.05)$ across the treatments with the highest value observed in goats fed $20 \%$ HPLM (8.36 mmol/l). Therefore, though the concentration of blood glucose observed for most of the treatments in this study fall within the normal range, goats on 10 and 20\% HPLM had higher glucose levels than the normal range. This therefore indicates that Hog plum leaf meal contains some glucose precursors which helped to prevent the occurrence of hypoglycaemia associated with excessive utilization of blood glucose in goats. The observed tendency toward decrease in blood glucose at high levels of HPLM and non-significant effect on total protein levels is in agreement with other investigations (Yazar et al., 2003; Dinev et al., 2007). The value of total protein for Red Sokoto goats is within the values reported by Tambual et al. (2002). The normal values for total protein in Red Sokoto goat has been reported to be 4.4$5.23 \mathrm{gd} / \mathrm{L}$ (Daramola et al., 2005). The nonsignificant increase in total protein values indicated that hog plum leaf meal had no negative effect on the health status of Red Sokoto bucks. The albumin values were slightly higher than the values reported by Bhat et al. (2011). The blood urea level in this study shows that Red Sokoto goats had lower value on $30 \%$ HPLM (4.46 mmol/L) than the other treatments. Serum creatinine levels were within normal range and increased with increase in hog plum leaf meal being highest on 40\% HPLM (147.0 $\mathrm{mmol} / \mathrm{L})$. The significant higher creatinine concentration observed in treatments containing Hog plum leaf meal in this study can be attributed to increase muscle mass and level of physical activity in the bucks. The sodium levels obtained in this study of 154.33 to $169.33 \mathrm{mmol} / \mathrm{L}$ was higher compared to the values of 129.3 to 131.0 $\mathrm{mmol} / \mathrm{lL}$ reported by Bhat et al. (2011). The reason for this high level of sodium observed in this study is not clear. The serum potassium level was higher in all the treatments studied when compared to the values of 4.3-4.5 mmol/L for Red Sokoto goats as reported by Bhat et al. (2011). The comparison generally reveals that there 
were no significant differences among all the treatment diets. The values for chloride show significant difference but are all within normal range.

\section{Conclusion}

The study indicated that up to $20 \%$ hog plum leaf meal can be included in the Red Sokoto buck diets without any adverse effect on haematological and serological indices and could be recommended for better economic returns.

\section{References}

Addass, P. A., Midau, A. and Babale, D. M. 2010. Heamato-biochemical findings of indigenous goats in Mubi, Adamawa State, Nigeria. Journal of Agricultural and Social Science, 6:14-16.

Adejumo, D. O. 2004. Performance, organ development and Haematological of Rats fed sole diets of graded levels of cassava flour and soybean flour (soy gari) as substitutes for energy and protein concentrates. Tropical Journal of Animal Science, 7:57-63.

Agenas, S., Health, M. F., Nixon, R. M., Wilkinson, J. M. and Phillips, C. C. 2006. Indicators of under nutrition in Animal. Animal Welfare, 15:149-160.

Ambros, R. T., Ketchum, D. F. and Smith, J. W. 1983. Creatinine determined by 'High performance' Liquid Chromatography. Clinical Chemistry, 29:256-259.

AOAC. 2005. Official Methods of Analysis, Association of Official Analytical Chemist, $17^{\text {th }}$ Edition, Washington D.C. U.S.A.

Aregheore, E. M., Abdulrazak, S. A. and Fujihara, T. 2003. Evaluation of some agri-industrial by-products available in Samoa for goats.
Asian-Australian Journal Animal

Science, 16(11): 1593-1598

Bhat, S. A., Manzoor, R., Qadir, M. S., Allaie, I., Kham, H. M., Hussain, I. and Bilal, S. 2011. Variation in haematological and serum biochemical indices of heep fed ziziphus mucronta and pakia biglobosa. International Journal of Agriculture and Veterinary Medicine Science, 5:481-487

Daramola, J. O. Adeleye, A. A., Fatoba, T. A. and Soladoye, A. O. 2005. Heamatological and biological parameters of West African Dwarf goats. Livestock Resources and Rural Development, 17:8

Dinev, T., Dimitrinka, Z. and lubomir L. 2007. Changes in some Blood biochemical and Haemotological parameters in goats after A minoglycoside and Aminocyclitol treatment at therapeutic Doses. Turkey Journal of Veterinary Animal Science, 31(3) 179-188.

Doumas, B., Bayse, D. D., Carter, R.J., Peters, T. and Schafer, R. 1981. A candidate reference method for Determination of Total protein in serum: 1. Development and validation. Clinical Chemistry, 27:1642.

Doumas. B. T. and Biggs, H. G. 1972. Determination of serum albumin. Standard method of Clinical Chemistry, 7:175-188.

Dunnett, C. W. 1955. "A Multiple Comparisons Procedure for Comparing Several Treatments with a Control," Journal of the American Statistical Association, 50:1096-1121

Famino, A, O., Oduguwa, O. O., Aiade, A. A., Ogunnaikke, T. O. and Adeshinwa, A. O. K. 2003. Growth performance, nutrients 
Effect of dietary levels of hog plum (Spondias mombin) leaf meal on blood profile

digestibility and carcass characteristics of rabbits fed cashew apple waste. Livestock Resources for Rural Development, $15(3): 1-7$.

Friday, O. Z., Joseph, O. A., Peter, I. R. and Muhammed, U. K. 2014. Effect of age, sex, physical activity and meteorological factors on haematological parameters of Donkeys (Equusa sinus). Comparative Clinical Pathology, 5(1):26-32.

Ganong, W. F. 2005. Review of Medical Physiology $22^{\text {nd }}$ edition Mcgraw Education, Asias. 45(9):516-532

Hang, W. and Lantzsch, H.J. 1983. Comparative methods for the rapid determination of oxalate and phytate in cereal products. Journal Science Food Agriculture, 34:4231426.

Harborne, I. B. 1973. Phytochemical Methods: A guide to Modern Techniques of Plant Analysis. $2^{\text {nd }}$ edition chapman and hall, New York, 88-185.

Isaac, L. J., Abah, G., Akpan, B. and Eka e t te, I . U. 2013 . Haematological properties of different breeds and sexes of rabbits. Proceeding of the $18^{\text {th }}$ Annual Conference of Animal Science Association of Nigeria, Pp24-27

Jain, N. C. 1986. Schalm's Veterinary Haematology, 4th edition. Lea and Febiger, Philadelphia. Pp 20-86.

Kopp, R. and Hetesa, J. 2000. Changes of Haemotological studies in adolescent breeding cocks. Acta veterenary. Brno, 69:189-194.

Kumar, R. 1991. Anti-nutritional factors: the potential risks of toxicity and methods to alleviate them. Proceeding of F.A.O Expert consultation held at the Malaysian
Agricultural Research and Development institute, Kuala Lumpur, Malaysia. Pp150.

Lindsay, D. B., Hunter, R. A., Gazzola, C., Spiers, W. G. and Sillence, M. N. 1993. Energy and Growth. Australian Journal of Agricultural Resources, 44:875-889.

Mapekula, M., Mapiye, C. and Chimonyo, M. 2011. Changes in metabolites concentration in Nguni and crossbred calves on natural pasture. Asian- Australian Journal of Animal Science, 24(11):15691576.

Ndlovu , T., Chimonyo, M., Okoh, A.I., Muchenje, V., Dzama, K. and Raats, J. G. 2007. Review: assessing the nutritional status of beef cattle: current practices and future prospects. African Journal of Biotechnology, 16(24):27272734.

NseAbasi N. E., Edem, E.A., Offiong, M. E., Williams, L. and Asuquo, E. 2014. Influence of nutrition on blood parameters of pigs. American journal of Biology and Life Science, 2(2):46-52.

Olabanji, R. O., Farinu, G.O., Akinlade, J. A. and Ojebiye, O. O. 2007. Growth performance and haematological characteristics of weaner rabbits fed cyanide in processed cassava peel meals on haematological and biochemical indices of growing rabbits. Proceeding of the $35^{\text {th }}$ Annual Conference of the Nigerian Society for Animal Production. $\mathrm{Pp} 212$.

Oladele, E. O. P. and Oshodi, A. A. 2008. Effect of fermentation on some chemical and nutritive properties of berlandier nettle spurge ( Jatropha cathartica) and physic nut of (Jatropha curcas) seeds. Pakistan Journal of Nutrition, 
Bishir, Iyeghe-Erakpotobor, Zahraddeen and Aliyu

7:292-296.

Opara, M. N., Udevi, N. and Okoli I. C. 2010. Heamatological parameters and Blood chemistry of Apparently Healthy West African Dwarf (WAD) Goats in Owerri, South Eastern Nigeria. New York Science Journal, 3(8):68-72.

Ovimaps, 2015. Ovi location map; Ovi Earth Imagery. Retrieved on $16^{\text {th }}$ November 2015.

Ovuru, S. S. and Ekweozor, I. K. E. 2004. Haematological changes associated with crude oil ingestion. African Journal of Biotechnology, 3:346-348.

Pambu-Gollah, R., Cronje, P. B. and Casey, N. H. 2000. An evaluation of the use of blood metabolite concentrations as indicators of nutritional status in free-ranging indigenous goats. South African Journal of Animal Science, 30:115120.

Pauzenga, U. 1985. Feeding parent stock, Zootecnica Interntional. Pp 22-24

Price, K. R., Johnson, I. T. and Fenwick, G. R. 1987. The chemistry and biological significance of saponins in foods and feeding stuffs. Crit. Rev. Food Science Nutrition, 26(1):27-135.

Sampson, E. J., Baird, M. A., Burtis, C. A., Smith, E. M., Witte, D. L. and Bayse, D. D. 1983. Coupledenzyme equilibrium method for measuring urea in serum: optimization and evaluation of the AACC Study group on urea candidates reference method. Clinical Chemistry, 26:816-826.

SAS Institute, inc. 2002. SAS User's guide: Statistics. Version 9. SAS Institute, carry, NC 27513, USA.

Schalm, O. W, Jain, N. C and Carrol E. J. 1975. Veterinary Haematology. $3^{\text {rd }}$ edition Lea Febiger Philadelphia
USA. Pp13 -167.

Sofowara, E.A. 1982. Medicinal Plants and Traditional Medicines in Africa. John Wiley and Sons Ltd, Nigeria, Pp 64-79.

Tambual, F. M., Agaie, B. M. and B a n g a n a , B. 2002 . Haematological and Biochemical values of apparently healthy Red Sokoto Goats. Proceedings $22^{\text {nd }}$ Annual Conference Nigerian Society of Animal Production (NSAP), March 17-21, 2002. Federal University of Technology, Akure, Nigeria, Pp. 50-53.

Thornton, P. K. and Herrero, M. 2010. The potential for reduced emissions from livestock and pasture manage- in the tropics . Proc. Natl Acad. Sci. USA

Tilman, D., Kenneth G. C. and Pamela, A. M., 2002. Agricultural sustainability and intensive production practices. International weekly of science, $\mathrm{Pp}$ 671-677; doi:10.1038/nature 01014.

Trease, G. E. and Evans, W. C. 1989. Pharmacognosy. $13^{\text {th }}$ Edn. BacilliereTinall Ltd, London, P57.

Trinder, P. 1969. Determination of glucose in blood using glucose oxidase with an alternative oxygen a c c e ptor. Enzymatic Determination of Total Serum Cholesterol. Annual Clinical Biochemistry, 6:24

Wettemann, R. P., Lents, C. A., Ciccioli, N. H., White, F. J. and Rubio, I. 2003. Nutritional and suckling mediated and an ovulation in beef cows (E. supplement 2). Journal of Animal Science, 81:48-59.

William, A. and Foyert, J. 1997. Veterinary Parasitology Reference Manual, 4th Edition. 
Effect of dietary levels of hog plum (Spondias mombin) leaf meal on blood profile

Yazar, E., Elmas, M., Altunok, V., Sivrikaya A., Oztekin, Birdane Y.O. 2003 . Effect of Aminoglycoside antibotics on $\mathrm{r}$ e $\mathrm{n}$ a $\mathrm{l}$ a $\mathrm{nt}$ i o x i d a n t s, malondialdehyde levels, and some serum biochemical parameters. Canadian Journal of Veterinary Research, 67:239-240.

Received: $17^{\text {th }}$ December, 2020

Accepted: $26^{\text {th }}$ February, 2021 